\title{
ANALISIS SELF EFFICACY PERAWAT BERDASARKAN DATA DEMOGRAFI DI TENGAH PANDEMI COVID-19
}

\section{SELF EFFICACY ANALYSIS OF NURSES BASED ON DEMOGRAPHIC DATA IN THE MIDDLE OF THE COVID-19 PANDEMIC}

\author{
Christianto Nugroho ${ }^{1 *}$, Ikhwan Kosasih ${ }^{2}$ \\ ${ }_{1,2}$ STIKes Pamenang \\ *Korespondensi Penulis : christiantonug@gmail.com
}

\begin{abstract}
Abstrak
COVID-19 telah menyebabkan krisis kesehatan global dengan meningkatnya jumlah orang yang terinfeksi dan meninggal setiap hari. Melihat banyaknya kasus dan gejala pasien covid-19 diatas memberi gambaran bahwa betapa banyaknya pasien dan resiko yang harus dihadapi oleh perawat, hal ini mempengarui psikologi perawat secara umum dan terkhusus mempengaruhi efficacy diri perawat tersebut. Tujuan penelitian ini adalah menganalisis self efficacy perawat berdasarkan data demografi ditengah pandemi covid-19. Penelitian ini bersifat deskripsi analitik dengan menggunakan pendekatan kuantitatif di RSUD Pare pada bulan april - september 2021. Populasi penelitian adalah semua perawat RS. Kabupaten Kediri. Jumlah sampel yang diambil 181 orang, Pengambilan data dilakukan dengan lembar kuesioner yang berisi tentang self efficay. Berdasarkan data tersebut diatas menunjukkan bahwa self efficacy sedang pada umur responden $26-35$ tahun $(35,4 \%)$, jenis kelamin terbanyak perempuan 73,5\%, tingkat pendidikan D-3 Keperawatan 69,1\%, lama kerja 2-10 tahun $38,7 \%$. Sedangkan analisis self efficacy berdasarkan data demografi ditunjukkan dengan varibel umur memiliki nilai $\mathrm{p}=0,001 \mathrm{r}=0,352$, jenis kelamin nilai $\mathrm{p}=0,045 \mathrm{r}=0,182$, pendidikan nilai $\mathrm{p}=0,513 \mathrm{r}=0,133$, lama kerja nilai $\mathrm{p}=0,007 \mathrm{r}=0,297$. Umur, jenis kelamin,pendidikan, dan lama kerja memberikan dukungan yang baik pada self efficacay seseorang dalam melakukan kegiatan, termasuk kondisi perawat selama pandemi covid-19, mereka mengalami perubahan self efficacy selama merawat pasien dengan covid-19.
\end{abstract}

Kata kunci : Self Efficacy, Demografi, Perawat, Covid-19

\begin{abstract}
COVID-19 has caused a global health crisis with the number of people getting infected and dying every day. Seeing the number of cases and symptoms of COVID-19 patients above illustrates how many patients and the risks nurses must face, this affects the psychology of nurses in general and in particular affects the nurse's self-efficacy. The purpose of this study was to analyze the selfefficacy of nurses based on demographic data amid the covid-19 pandemic. This research is an analytical description using a quantitative approach at Pare Hospital in April-September 2021. The research population is all hospital nurses. Kediri Regency. The number of samples taken was 181 people. Data was collected using a questionnaire sheet containing self-efficacy. Based on the data above, it shows that self-efficacy is moderate at the age of the respondent 26-35 years (35.4\%), the most gender is female $73.5 \%$, education level D-3 Nursing $69.1 \%$, length of work 2-10 years $38,7 \%$. While the self-efficacy analysis based on demographic data is indicated by the age variable having $p$-value $=0.001 r=0.352$, gender $p=0.045 r=0.182$, education $p$-value $=0.513 r=0.133$, length of work $p=0.007 r=0.297$. Age, gender, education, and length of work provide good support for a person's self-efficacy in carrying out activities, including the condition of nurses during the covid-19 pandemic, they experience changes in self-efficacy while caring for patients with covid-19.
\end{abstract}

Keywords : Self Efficacy, Demographics, Nurses, Covid-19

Submit/ unggah : 19 November 2021, Accepted : 25 November 2021

Website : jurnal.stikespamenang.ac.di | Email : jurnal.pamenang@gmail.com 


\section{Pendahuluan}

COVID-19 telah menyebabkan krisis kesehatan global dengan meningkatnya jumlah orang yang terinfeksi dan meninggal setiap hari. Berbagai negara telah mencoba mengendalikan penyebarannya dengan menerapkan prinsip-prinsip dasar pengelompokan dan pengujian sosial. Profesional kesehatan telah menjadi pekerja garis depan secara global dalam menghadapi persiapan dan pengelolaan pandemi ini (ElHage et al., 2020)(Rosyanti and Hadi, 2020). Petugas kesehatan menderita stres yang hebat dan tekanan psikologis selama epidemi penyakit menular(Xiong, Yi and Lin, 2020). Menghadapi situasi kritis, petugas kesehatan di garis depan yang terlibat langsung dalam diagnosis, pengobatan, dan perawatan pasien Covid-19 berisiko mengalami gangguan psikologis berupa depresi dan gejala kesehatan mental lainnya. Berbagai faktor telah diteliti dan dilaporkan diantaranya beban kerja yang berat, peralatan perlindungan pribadi yang menipis, liputan media yang terlalu sering dan meluas, kurangnya obat-obatan tertentu, dan perasaan tidak didukung secara memadai turut berkontribusi pada beban mental tenaga kesehatan(Rejo, Dewi Arradini, Darmayanti, Aquartuti Tri, Widiyanto and Atmojo, 2020) Data pasein yang terkonfirmasi positif di indonesia per tanggal 23 oktober 2020 menyentuh angka 377.541 sembuh 301.006 meninggal 12.959 (Satgas Nasional, 2020), di jawa timur mencapai angka terkonfirmasi positif 50.069 sembuh 44.018 , meninggal dunia 3619 dan di rumah sakit umum daerah kabupaten kediri pasien terkonfirmasi positif dengan dirawat ventilator 12 , tanpa ventilator 26 rawat biasa 39 (Satgas Jatim, 2020).

Penting untuk memahami gejala klinis COVID-19, meskipun gejala klinis yang ditunjukkan tidak spesifik. Gejala umum termasuk demam, batuk, mialgia, dan kelelahan. Pasien awalnya mungkin datang dengan diare dan mual beberapa hari sebelum mengalami demam, yang menunjukkan bahwa demam dominan tetapi bukan gejala utama infeksi. Sejumlah kecil pasien dapat mengalami sakit kepala atau hemoptisis(Zhong and Liu, 2020)(Zu et al., 2020) dan relatif asimtomatik( $\mathrm{Zu}$ et al., 2020) (Chan et al., 2020). Laki-laki tua yang terkena dengan komorbiditas lebih mungkin mengalami kegagalan pernapasan karena kerusakan alveolar yang parah(Zu et al., 2020)(Chen et al., 2020). Onset penyakit dapat menunjukkan perkembangan yang cepat menjadi disfungsi organ (misalnya, syok, sindrom gangguan pernapasan akut, cedera jantung akut, dan cedera ginjal akut) dan bahkan kematian pada kasus yang parah(Zu et al., 2020)(Huang et al., 2020).

Melihat banyaknya kasus dan gejala pasien covid-19 diatas memberi gambaran bahwa betapa banyaknya pasien dan resiko yang harus dihadapi oleh perawat, hal ini mempengarui psikologi perawat secara umum dan terkhusus mempengaruhi efficacy diri perawat tersebut. Efikasi diri mencerminkan keyakinan dan rasa percaya diri apakah individu dapat menggunakan kapasitasnya untuk mencapai tugas. Efikasi diri terkait dengan tingkat motivasi, tindakan, dan keadaan psikologis(Bandura, 1997). Schwarzer mengangkat konsep self-efficacy umum, yang mengacu pada kepercayaan diri individu secara keseluruhan dalam menghadapi tantangan yang berbeda konteks lingkungan atau masalah yang berkembang(Schwarzer et al., 1997), Selfefficacy perawat berkorelasi dengan mental kesehatan, ketahanan, dan kelelahan kerja (Hsieh, Wang and Ma, 2019). Selama wabah SARS, petugas kesehatan dengan efikasi diri rendah mengalami ketakutan yang lebih tinggi.(Ho et al., 2005) Selain itu, efikasi diri merupakan faktor penting dalam memprediksi kesediaan untuk merawat pasien dengan penyakit infeksi yang sedang berkembang(Lee and Kang, 2020).

Untuk hal itu perlu penelusuran lebih mendalam terkait dengan self efficacy perawat selama pandemi covid-19 ini, sehingga peneliti tertarik meneliti tentang self efficacy perawat ditengah pandemi covid-19. Tujuan penelitian ini adalah menganalisis self efficacy perawat berdasarkan data demografi ditengah pandemi covid-19 di RS. kabupaten kediri, Jawa Timur, Indonesia

\section{Metode}

Penelitian ini bersifat deskripsi analitik dengan menggunakan pendekatan kuantitatif di RSUD Pare pada bulan april - september 2021. Populasi penelitian adalah semua perawat RS. Kabupaten Kediri. Jumlah sampel yang diambil 181 orang, Pengambilan data dilakukan dengan lembar kuesioner yang berisi tentang self efficay. Data yang terkumpul selanjutnya diolah, ditabulasi dan dilakukan 
analisis. Analisis bivariat menggunakan uji kendal tau dan koefisien kotigensi, analisis kendal tau untuk menguji hubungan antara faktor demografi (umur, jenis kelamin, pendidikan, dan lama kerja) dengan self efficacy dengan tingakt kepercayaan 95\% (p value $<0,05$ ), sedangkan uji kekuatan antar hubungannya dengan menggunakan uji koefesien kontigensi.

\section{Hasil}

Hasil penelitian ini menyajikan analisis self efficacy perawat berdasarkan data demografi ditengah pandemi covid-19.

\begin{tabular}{|c|c|c|c|}
\hline \multirow{2}{*}{ Variabel } & \multicolumn{3}{|c|}{ Self Efficacy } \\
\hline & $\sum$ & $\%$ & sig \\
\hline $\begin{array}{l}\text { Umur : } \\
\text { - } \quad<25 \text { tahun } \\
\text { - } \quad 26-35 \text { tahun } \\
\text { - } \quad 36-45 \text { tahun } \\
\text { - } \quad 46-55 \text { tahun } \\
\text { - } \quad>55 \text { tahun }\end{array}$ & $\begin{array}{l}53 \\
64 \\
37 \\
26 \\
1 \\
\end{array}$ & $\begin{array}{l}29,3 \% \\
35,4 \% \\
20,4 \% \\
14,4 \% \\
0,6 \%\end{array}$ & $\begin{array}{l}\rho \quad= \\
0,001 \\
r=0,352\end{array}$ \\
\hline $\begin{array}{l}\text { Jenis Kelamin : } \\
\text { - } \quad \text { Laki - Laki } \\
\text { - } \quad \text { Perempuan }\end{array}$ & $\begin{array}{l}48 \\
133\end{array}$ & $\begin{array}{l}26,5 \% \\
73,5 \%\end{array}$ & $\begin{array}{l}\rho \quad= \\
0,045 \\
r=0,182\end{array}$ \\
\hline $\begin{array}{l}\text { Pendidikan : } \\
\text { - } \quad \text { D-3 } \\
\text { Keperawatan } \\
\text { - } \quad \text { S-1 } \\
\text { Keperawatan } \\
\text { - S-2 } \\
\text { Keperawatan }\end{array}$ & $\begin{array}{l}125 \\
54 \\
2\end{array}$ & $\begin{array}{l}69,1 \% \\
29,8 \% \\
1,1 \%\end{array}$ & $\begin{array}{l}\rho \quad= \\
0,513 \\
r=0,133\end{array}$ \\
\hline $\begin{array}{l}\text { Lama Kerja: } \\
\text { - } \quad<1 \text { tahun } \\
\text { - } \quad 2-10 \text { tahun } \\
\text { - } 11-20 \text { tahun } \\
\text { - } \quad>20 \text { tahun }\end{array}$ & $\begin{array}{l}41 \\
70 \\
36 \\
34\end{array}$ & $\begin{array}{l}22,7 \% \\
38,7 \% \\
19,9 \% \\
18,8 \%\end{array}$ & $\begin{array}{l}\rho \quad= \\
0,007 \\
r=0,297\end{array}$ \\
\hline
\end{tabular}

Berdasarkan data tersebut diatas menunjukkan bahwa self efficacy sedang pada umur responden 26-35 tahun (35,4\%), jenis kelamin terbanyak perempuan $73,5 \%$, tingkat pendidikan D-3 Keperawatan 69,1\%, lama kerja 2-10 tahun $38,7 \%$. Sedangkan analisis self efficacy berdasarkan data demografi ditunjukkan dengan varibel umur memiliki nilai $\mathrm{p}=0,001 \mathrm{r}=0,352$, jenis kelamin nilai $\mathrm{p}$ $=0,045 \mathrm{r}=0,182$, pendidikan nilai $\mathrm{p}=0,513 \mathrm{r}$ $=0,133$, lama kerja nilai $\mathrm{p}=0,007 \mathrm{r}=0,297$.

\section{Pembahasan}

Pandemi COVID-19 dirasakan oleh sekelompok personel rumah sakit (tenaga medis, teknis, dan pemeliharaan) sebagai ancaman nyata. Sebagian besar responden khawatir tertular COVID-19. Menurut model adaptasi stres, pengalaman ketakutan dan stres didefinisikan sebagai respons yang dialami secara universal terhadap keadaan kehidupan yang luar biasa (Valdez and Nichols, 2013). Kekhawatiran tertular virus corona mungkin juga berasal dari tingginya kesadaran staf rumah sakit bahwa virus dapat diserap oleh selsel selaput lendir di mata, hidung, pipisetelah itu mengubah kode genetiknya, berlipat ganda, dan bertransformasi. selnya sendiri ke dalam sel si penyusup. Virus tidak terlihat dan mungkin ada di mana-mana-dalam napas pasien, pada pakaiannya, barang-barang yang dimilikinya, dan pada semua yang disentuhnya. Hal ini mudah menular. Oleh karena itu, personel rumah sakit mungkin menganggap virus sebagai ancaman nyata yang tidak terlihat bagi mereka dan semua orang yang mereka hubungi (termasuk teman dekat dan kerabat mereka). Ini bisa menjelaskan ketakutan mereka yang sebenarnya terhadap virus corona. Persepsi situasi sendiri sebagai ancaman dapat memperdalam rasa tidak aman. Biasanya, pada saat pandemi, prosedur pemantauan infeksi dan rekomendasi kesehatan masyarakat sering diubah. Perubahan dapat diperkenalkan setiap hari atau bahkan setiap jam, yang menjelaskan peningkatan tingkat ketidakamanan pada tenaga medis. Tampaknya siaran media juga mengintensifkan rasa tidak aman dan kecemasan. Penelitian juga menunjukkan bahwa staf tidak memiliki perencanaan dan solusi strategis bagi masyarakat di berbagai tingkatan pada saat bencana, yang juga meningkatkan rasa tidak aman dan kecemasan saat menghadapi ancaman(Roudini et al., 2017).

Kami berasumsi bahwa rasa efikasi diri akan menjadi sumber daya yang signifikan di tengah pandemi COVID-19. Skor GSES berkorelasi negatif dengan ketakutan tertular virus corona serta kecemasan tentang konsekuensi COVID-19. Rasa efikasi diri personel rumah sakit terutama didasarkan pada pendidikan, keterampilan praktis, dan pengetahuan ahli mereka, sehingga bahkan kurangnya sumber daya eksternal, seperti masker pelindung yang mereka miliki, pelindung wajah, kacamata, sarung tangan sekali pakai, mantel pelindung dan baju pelindung, dan cairan desinfektan, tidak 
menurunkan rasa efikasi diri pada semua kelompok staf rumah sakit. Kecemasan telah terbukti meningkatkan kepekaan terhadap tekanan kerja dan lingkungan kerja dan memiliki efek negatif pada efikasi diri karena mengurangi perilaku dan inisiatif positif (Xiao et al., 2020).

\section{Analisis faktor demografi umur dengan self efficacy}

Hasil analisis terdapat hubungan yang signifikan antara umur dengan self efficacy dengan nilai $\mathrm{p}$ value sebesar $0,001 \quad(\mathrm{p}$ value $<0,05$ ). Sebagian besar responden berusia direntang 26 - 35 tahun yaitu 64 responden $(35,4 \%)$. Didapatkan juga direntang umur $26-$ 35 tahun memiliki self efficacy rendah 3 responden $(4,7 \%)$, sedang 54 responden $(84,4 \%)$ dan Baik 7 responden (10,9\%). Sebaliknya yang memiliki self efficacy baik pada usia < 25 tahun 10 (37\%), 26-35 tahun 7 $(25,9 \%), 36-45$ tahun $4(14,8 \%), 46-55$ tahun 6 $(22,2 \%)$. Variabel faktor demografi umur mempunyai nilai $r$ sebesar 0,352 yang berarti bahwa antara varibel umur dengan self efficacy memiliki hubungan yang positif dengan kekuatan hubungan lemah (rentang 0,2-0,399). Melihat hasil self efficacy yang baik manyoritas terdapat di umur $<25$ tahun, hal ini dimungkinkan terjadi dikarenakan pada umur ini mudah untuk melakukan adapatasi yang baik, dan pada umur ini memiliki tekad yang kuat untuk menyelesaikan masalah, sehingga pada kondisi umur ini mampu beradaptasi dengan kondisi pandemi covid-19 ini. Individu yang memiliki usia pertengahan lebih sering mengalami perubahan fisik dan mental, dalam hal ini individu lebih rentan mengalami sakit, mereka memiliki tekad untuk berusahan menyelesaikan permasalahan dengan mencapai suatu tujuan yang diinginkan, dalam hal ini berupa kesehatan. Pada aktivitas mencapai kesuksesan dalam menyelesaikan suatu masalah, individu tersebut dapat meningkatkan self efficacy yang mampu mempertahankan dan meningkatkan kesehatannya. (Ismatika and Soleha, 2018).

Pada usia 26 -35 tahun juga memiliki jelajah informasi yang cepat melalui media sosial yang ada, seperti yang disampaikan bahwa antara umur 26-45 merupakan usia dewasa dengan pertimbangan individu dengan umur tersebut akan mempunyai midset yang cukup baik sehingga pola pikir akan informasi yang dimilikinya juga akan semakin membaik. (Winugroho et al., 2021)

Banyak peneliti telah menyarankan bahwa usia dapat mempengaruhi efikasi diri mengingat, secara umum, orang yang matang telah mengembangkan kemampuan yang lebih baik dalam berpikir dan melakukan tugas (Molinari and Monserud, 2008)(Simonetti et al., 2021).

\section{Analisis faktor demografi jenis kelamin dengan self efficacy}

Hasil analisis terdapat hubungan yang signifikan antara jenis kelamin dengan self efficacy dengan nilai $p$ value sebesar $p=0,045$ ( $p$ value $<0,05$ ). Sebagian besar responden berjenis kelamin perempuan yaitu 133 responden $(73,5 \%)$. Didapatkan juga rentang jenis kelamin perempuan memiliki self efficacy rendah 4 responden $(3,0 \%)$, sedang 133 responden $(85 \%)$ dan baik 16 responden $(12 \%)$ serta hasil self efficacy yang baik Lakilaki $11(40,7 \%)$ dan Perempuan 16 (58,3\%). Variabel faktor demografi jenis kelamin mempunyai nilai $r$ sebesar 0,182 yang berarti bahwa antara varibel jenis kelamin dengan self efficacy memiliki hubungan yang positif dengan kekuatan hubungan sangat lemah (rentang 0,1-0,299).

Wanita dan mereka yang memiliki tingkat kekhawatiran yang lebih tinggi tentang pandemi COVID-19 lebih cenderung mencari bimbingan. Selama masa ketidakpastian ini, model peran dicari lebih dari dukungan karir dan dukungan psikososial. Ketiga fungsi pencarian bimbingan secara positif terkait dengan tingkat efikasi diri yang lebih tinggi.(van Esch, Luse and Bonner, 2021)

Laki-laki, perawat yang lebih tua, mereka yang memiliki pengalaman kerja jangka panjang dan mereka yang mengikuti kursus pascapendaftaran mengalami tingkat efikasi diri yang lebih tinggi, membantu mereka dalam meningkatkan kinerja pribadi dalam menghadapi kesulitan.(Amini and Noroozi, 2018)

Self efficacy merupakan keyakinan dalam kemampuan seseorang untuk mengatur dan melaksanakan program tindakan yang diperlukan untuk mengelola situasi yang akan terjadi (Christianto Nugroho, 2015). Hal ini menunjukkan bahwa ada faktor lain selain empat elemen self efficacy yang mempengaruhi self efficacy pada individu, walaupun faktor tersebut tidak berdiri sendiri 
tetapi mempengaruhi secara bersama- sama, ini sesuai dengan teori Bandura yang menyatakan seain ke empat sumber efficacy dan proses informasi dapat juga dipengaruhi dari kaakteristik individu dan lingkungan. secara ideal self efficacy diperkuat melali berbagai pengalaman yang berhubungan dan akan mempengaruhi perilaku selanjutnya. Seseoang akan memutuskan untuk berperilaku berdasarkan pada pemikiran reflektif, penggunaan pengetahuan secara umum dan kemampuan untuk melakukan satu tindakan. (C. Nugroho, 2020)(C Nugroho, 2015)

\section{Analisis faktor demografi pendidikan dengan self efficacy}

Hasil analisis tidak terdapat hubungan yang signifikan antara pendidikan dengan self efficacy dengan nilai $\mathrm{p}$ value sebesar $\mathrm{p}=0,513$ ( $p$ value $<0,05$ ). Sebagian besar responden berpendidikan D-3 Keperawatan yaitu 125 responden $(69,1 \%)$. Didapatkan juga rentang pendidikan D-3 Keperawatan memiliki self efficacy rendah 5 responden (4\%), sedang 104 responden $(83,2 \%)$ dan baik 16 responden $(12,8 \%)$. Variabel faktor demografi pendidikan mempunyai nilai $r$ sebesar 0,133 yang berarti bahwa antara varibel pendidikan dengan self efficacy memiliki hubungan yang positif dengan kekuatan hubungan sangat lemah (rentang 0,1-0,299).

Bandura berteori bahwa individu dengan tingkat pendidikan yang lebih tinggi (dalam hal ini kursus pasca-registrasi) akan belajar lebih banyak melalui pendidikan formal sehingga mereka mendapatkan lebih banyak kesempatan untuk belajar mengatasi masalah. Managemen diri difokuskan pada keterlibatan semua sumber data yang ada disekitar pasien sehingga akan lebih percaya diri dan meningkatkan perilaku.(Nugroho et al., 2020)

\section{Analisis faktor demografi lama kerja dengan self efficacy}

Hasil analisis terdapat hubungan yang signifikan antara lama kerja dengan self efficacy dengan nilai $p$ value sebesar $p=0,007$ ( $p$ value <0,05). Sebagian besar responden mempunyai lama kerja 2 - 10 tahun yaitu 70 responden $(38,7 \%)$. Didapatkan juga rentang lama kerja 2- 10 tahun memiliki self efficacy sedang 64 responden $(91,4 \%)$ dan baik 6 responden $(8,6 \%)$. Variabel faktor demografi lama kerja mempunyai nilai $\mathrm{r}$ sebesar 0,297 yang berarti bahwa antara varibel lama kerja dengan self efficacy memiliki hubungan yang positif dengan kekuatan hubungan lemah (rentang 0,2-0,399).

Pengalaman kerja (layanan yang lebih lama) juga terkait dengan efikasi diri yang lebih baik, sebagaimana didukung oleh bukti (Gloudemans, Schalk and Reynaert, 2013).

\section{Kesimpulan}

Self Efficacy mengacu pada harapan dan keyakinan mengenai mereka untuk berhasil melakukan tugas individu dengan efikasi yang tinggi tidak mudah berhenti, tetapi lebih memlih usahanya untuk mnegatasi tantangan. Umur, jenis kelamin,pendidikan, dan lama kerja memberikan dukungan yang baik pada self efficacay seseorang dalam melakukan kegiatan, termasuk kondisi perawat selama pandemi covid-19, mereka mengalami perubahan self efficacy selama merawat pasien dengan covid-19. Pendidikan dan pelatihan sistematis serta upaya organisasi untuk mempromosikan self efficacy, sangat penting utuk meningkatkan niat keperawatan perawat garis depan selama wabah infeksi baru.

\section{Ucapan Terima Kasih}

Penulis mengucapkan terima kasih kepada semua pihak yang terlibat dalam penelitian ini meliputi Direktorat Riset dan Pengabdian Masyarakat DPRM Kemenristek Dikti dan RS Kabupaten Kediri.

\section{Daftar Pustaka}

Amini, m. T. And noroozi, r. (2018) 'relationship between self-management strategy and selfefficacy among staff of ardabil disaster and emergency medical management centers tt ', hdqir, 3(2), pp. 85-90. Doi: 10.29252/nrip.hdq.3.2.85.

Bandura, a. (1997) self-efficacy: the exercise of control. Worth publishers. Available at: https://books.google.co.id/books?id=ejpn9g_o-ec.

C. Nugroho, s. (2020) 'analisis self efficacy peserta pelatihan penanganan analyze the selfefficacy of training participants in emergency', jurnal ilmiah pamenang, 2(2), pp. 42-47. Available at: https://jurnal.stikespamenang.ac.id/index.ph p/jip/article/view/73.

Chan, j. F.-w. Et al. (2020) 'a familial cluster of pneumonia associated with the 2019 novel coronavirus indicating person-to-person transmission: a study of a family cluster', the lancet, 395(10223), pp. 514-523. Doi: 
https://doi.org/10.1016/s0140-

6736(20)30154-9.

Chen, n. Et al. (2020) 'epidemiological and clinical characteristics of 99 cases of 2019 novel coronavirus pneumonia in wuhan, china: a descriptive study', the lancet, 395(10223), pp. 507-513. Doi: https://doi.org/10.1016/s01406736(20)30211-7.

El-hage, w. Et al. (2020) '[health professionals facing the coronavirus disease 2019 (covid19) pandemic: what are the mental health risks?].', l'encephale, 46(3s), pp. S73-s80. Doi: 10.1016/j.encep.2020.04.008.

Van esch, c., luse, w. And bonner, r. L. (2021) 'the impact of covid-19 pandemic concerns and gender on mentor seeking behavior and selfefficacy', equality, diversity and inclusion: an international journal, ahead-ofprint(ahead-of-print). Doi: 10.1108/edi-092020-0279.

Gloudemans, h. A., schalk, r. M. J. D. And reynaert, w. (2013) 'the relationship between critical thinking skills and self-efficacy beliefs in mental health nurses', nurse education today, 33(3), pp. 275-280. Doi: https://doi.org/10.1016/j.nedt.2012.05.006.

Ho, s. M. Y. Et al. (2005) 'fear of severe acute respiratory syndrome (sars) among health care workers.', journal of consulting and clinical psychology, 73(2), pp. 344-349. Doi: 10.1037/0022-006x.73.2.344.

Hsieh, y.-h., wang, h.-h. And ma, s.-c. (2019) 'the mediating role of self-efficacy in the relationship between workplace bullying, mental health and an intention to leave among nurses in taiwan', international journal of occupational medicine and environmental health, 32(2), pp. 245-254. Doi: 10.13075/ijomeh.1896.01322.

Huang, c. Et al. (2020) 'clinical features of patients infected with 2019 novel coronavirus in wuhan, china', the lancet, 395(10223), pp. 497-506.

https://doi.org/10.1016/s0140-

6736(20)30183-5.

Ismatika, i. And soleha, u. (2018) 'hubungan self efficacy dengan perilaku self care pasien pasca stroke di rumah sakit islam surabaya', journal of health sciences, 10(2), pp. 139148. Doi: 10.33086/jhs.v10i2.140.

Lee, j. And kang, s. J. (2020) 'factors influencing nurses' intention to care for patients with emerging infectious diseases: application of the theory of planned behavior.', nursing \& health sciences, 22(1), pp. 82-90. Doi: $10.1111 /$ nhs. 12652 .

Molinari, d. L. And monserud, m. (2008) 'rural nurse cultural self-efficacy and job satisfaction', journal of transcultural nursing, 20(2), pp. 211-218. Doi: $10.1177 / 1043659608330350$.

Nugroho, c. (2015) improving self-efficacy using caring-based self-efficacy enhancement intervention program in patients with type 2 diabetes mellitus. Universitas airlangga. Doi: $10.13140 /$ rg.2.2.36810.18883.

Nugroho, c. (2015) 'self efficacy pasien diabetes mellitus tipe 2 di wilayah kerja bpjs cabang kediri', jurnal ilmiah pamenang, 1(2), pp. 19-22.

Nugroho, c. Et al. (2020) 'analysis of home care services as patient expectation during', pp. 27-30.

Rejo, dewi arradini, darmayanti, aquartuti tri, widiyanto, a. And atmojo, j. T. (2020) 'faktor-faktor yang berhubungan dengan depresi pada tenaga kesehatan saat pandemi covid-19', urnal ilmu keperawatan jiwa, 3(4), pp. 495-502. Available at: http://journal.ppnijateng.org/index.php/jikj/ article/viewfile/682/371.

Rosyanti, 1. And hadi, i. (2020) 'dampak psikologis dalam memberikan perawatan dan layanan kesehatan pasien covid-19 pada tenaga profesional kesehatan', health information: jurnal penelitian, 12(1), pp. 107-130. Doi: 10.36990/hijp.vi.191.

Roudini, j. Et al. (2017) 'community mental health preparedness in disasters: a qualitative content analysis in an iranian context tt -', hdqir, 2(4), pp. 165-178. Doi: 10.29252/nrip.hdq.2.4.165.

Satgas jatim (2020) peta sebaran covid-19 jawa timur, infojatim.covid-19. Available at: http://infocovid19.jatimprov.go.id/ (accessed: 23 october 2020).

Satgas nasional (2020) data sebaran covid-19, covid-19. Available at: https://covid19.go.id/ (accessed: 23 october 2020).

Schwarzer, r. Et al. (1997) 'the assessment of optimistic self-beliefs: comparison of the german, spanish, and chinese versions of the general self-efficacy scale', applied psychology, 46(1), pp. 69-88. Doi: 10.1111/j.1464-0597.1997.tb01096.x.

Simonetti, v. Et al. (2021) 'anxiety, sleep disorders and self-efficacy among nurses during covid-19 pandemic: a large cross-sectional study', journal of clinical nursing, 30(9-10), pp. 1360-1371. Doi: https://doi.org/10.1111/jocn.15685.

Valdez, c. D. And nichols, t. W. (2013) 'motivating healthcare workers to work during a crisis : a literature review', 14(4), pp. 43-51. Available

at: https://scholar.google.com/scholar_lookup? journal=jmpp\&title $=$ motivating + healthcare +workers+to+work+during+a+crisis:+a+lit 
erature+review.\&author $=$ c. + h. + d. + valdez\& author $=$ t.+w.+nichols \&volume $=14 \&$ publica tion_year=2013\&pages $=43-51 \&$.

Winugroho, t. Et al. (2021) 'analisis pengaruh faktor demografi terhadap lama karantina pada perawat terpapar covid-19 di jawa tengah', pendipa journal of science education, 5(2), pp. 229-236. Doi: 10.33369/pendipa.5.2.229-236.

Xiao, h. Et al. (2020) 'the effects of social support on sleep quality of medical staff treating patients with coronavirus disease 2019 (covid-19) in january and february 2020 in china.', medical science monitor : international medical journal of experimental and clinical research, 26, p. E923549. Doi: 10.12659/msm.923549.

Xiong, h., yi, s. And lin, y. (2020) 'the psychological status and self-efficacy of nurses during covid-19 outbreak: a crosssectional survey', inquiry (united states), 57(201). Doi: 10.1177/0046958020957114.

Zhong, n. And liu, z. (2020) 'clinical characteristics of 2019 coronavirus pneumonia', (518061). Available at: https://www.medrxiv.org/content/medrxiv/e $\operatorname{arly/2020/03/10/2020.03.07.20032573.full.~}$ pdf.

Zu, z. Y. Et al. (2020) 'coronavirus disease 2019 (covid-19): a perspective from china', radiology, 296(2), pp. E15-e25. Doi: 10.1148/radiol.2020200490. 